
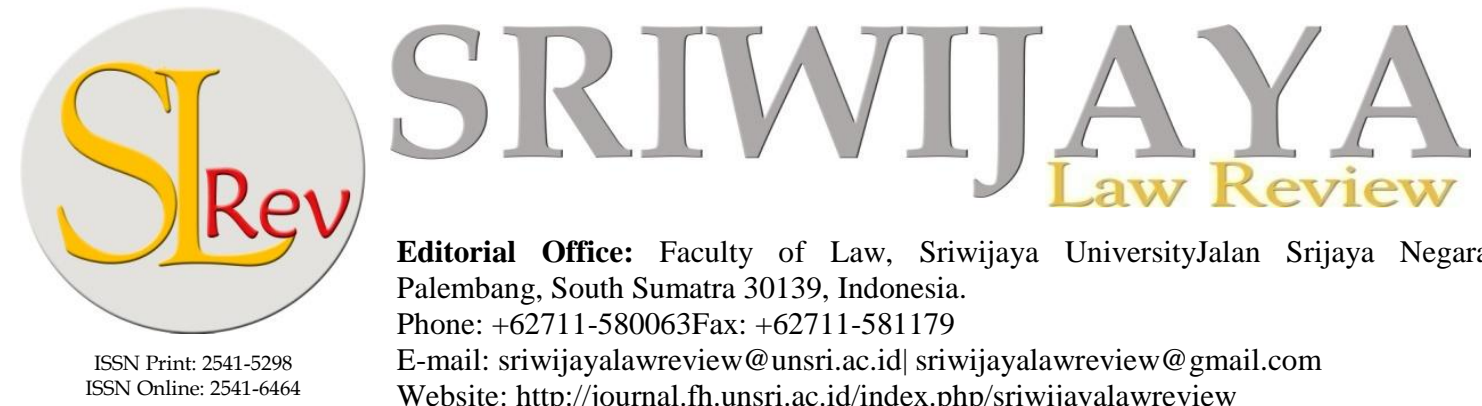

Editorial Office: Faculty of Law, Sriwijaya UniversityJalan Srijaya Negara, Palembang, South Sumatra 30139, Indonesia. Phone: +62711-580063Fax: +62711-581179

E-mail: sriwijayalawreview@unsri.ac.id|sriwijayalawreview@gmail.com Website: http://journal.fh.unsri.ac.id/index.php/sriwijayalawreview

\title{
The Indonesian Constitutional System in the Post Amendement of the 1945 Constitution
}

\author{
Zen Zanibar
}

\begin{abstract}
The 1945 Constitution of the Republic of Indonesia was amended for four times between 1999 and 2002) in the reformation era. These constitutional changes have altered the principles and the structure of the Indonesian primary state's institutions. Broadly speaking, all of the power branches - i.e. legislative, executive and judiciary organs- are now interrelated horizontally in running the country and none of them is superior to the others. Such constitutional system is generally found in countries that employ a presidential system. However, by reviewing the authority hold by the legislatures, it is found that some characteristics of a parliamentary system are also applied in Indonesia.
\end{abstract}

Keywords: Indonesian constitutional system; Reformation era; The 1945 Constitution.

\section{ARTICLE HISTORY :}

\section{DOI: 10.28946/slrev.Vol2.Iss1.109.pp45-55}

Received: Apr 11, 2017;

Reviewed: May 10, 2017;

Accepted: July 10, 2017;

Published: Jan 31, 2018;

Citation: V.2.1 SLRev. 2018.

Faculty of Law, Sriwijaya University

E-mail:zzen78@yahoo.co.id

\section{INTRODUCTION}

The amendments of the 1945 Indonesian Constitution (UUD) ${ }^{1}$ through four plenary sessions of the People's Consultative Assembly (MPR) ${ }^{2}$ - conducted in 1999 to 2002 - can be said a revolutionary constitutional changes. Within the newly amended Constitution, there are

\footnotetext{
${ }^{1}$ Hereinafter cited as UUD

${ }^{2}$ Hereinafter cited as MPR
}

74 new articles that regulated 174 provisions - and only approximately 25 provisions that remaining from the original UUD of 1945. Furthermore, the changes of the Indonesian Constitution are not limited to add or subtract the authority of the primary state's institutions, but also fundamentally changed the role of those institutions.

However, a constitutional change is something that should be anticipated. From the very beginning when UUD of 1945 was ratified on August 18, 1945, Soekarno - one of a prominent founding father and the first President of the Republic of Indonesia - in his speech said that the UUD of 1945 is a rushed Constitution that would be fixed sometime in the future when the national stability has well established and the environment has 
supported to make another constitutional change. Therefore, from the beginning it is realized that the status of the UUD of 1945 is actually a provision/ temporary Constitution.

An attempt to change the Constitution was tried in 1955 general elections that formed the Constitutional Assembly (Konstituante) in order to establish a permanent Constitution for the Republic of Indonesia - replacing the Provisional Constitution (UUD Sementara) of $1950 .^{3}$ But, the efforts that have been spent for a constitutional change failed due to considerable debate and conflict between different political factions which resulted to the parliamentary deadlock and political turmoil that led to the stipulation of the Presidential Decree on the $5^{\text {th }}$ of July 1959 that re-imposed the UUD of 1945.

Regardless of the absence of an academic draft as a pre-conceptual framework with regard to these constitutional changes in the Reformation situation that required a rapid pace to response the changing conditions, it is more important to carefully observe the changes themselves that have happened in the UUD of 1945.

\footnotetext{
3 The UUD of 1945 was ineffective due to political disturbances and military conflicts as resulted from the disputes between Indonesia and the Netherlands, until the Round Table Conference was conducted in Den Haag that resulted to the recognition of the Netherlands to the Republik Indonesia Serikat (RIS/ the United States of Indonesia) and its Constitution (Konstitusi RIS) that would be effective on December 27, 1949. The political dynamics in Indonesia resulted to the reunification of Indonesia and led to the replacement of the Konstitusi RIS with the UUD Sementara (Temporary/Provisional Constitution) of 1950 that was ratified on August 17, 1950.
}

There are at least two important things that can be identified in these cons-titutional changes. Firstly, the paradigm shift on the constitutional law; and, secondly, the institutional changes. These constitutional changes have dragged the Indonesian entering the new political arena that completely different from the previous three decades.

\section{ANALYSIS AND DISCUSSION Paradigm Shift on the Constitutional Law}

The UUD of 1945 comprises of different vision and mission between the pre- and the post-amendments. The debate on the conception of the unitary state of Indonesia (integralistik staatsidee) ${ }^{4}$ which is until 1994 has been questioned of whether such integralistik staatsidee has really vanished? Indeed, for 32 years of the Suharto's New Order era, the state's powers were concentrated in his hands as the President of the Republic of Indonesia under the UUD of 1945. This phenomenon - which is called 'executive heavy, ${ }^{5}$ - has challenged the Soepomo's conceptual idea of the 'integralistik' state of Indonesia. ${ }^{6}$

Is the 32 years of the Suharto's New Order era, as well as the previous

\footnotetext{
${ }^{4}$ Hereinafter cited as integralistik staatsidee

${ }^{5}$ Referred to the 16 articles out of 37 articles of the pre-amended UUD of 1945 that regulates the authority of the President, practically the Constitution provides a maximum authority to the President to become a conductor of governmental symphony.

6 Professor Soepomo is the principal drafter of the UUD of 1945.Sekretariat Negara, Risalah Sidang BPUPKI dan PPKI, $3^{\text {rd }}$ Ed., Jakarta: Sekretariat Negara, 1995; Marsilam Simanjuntak,Pandangan Negara Integralistik, 1st Ed., Jakarta: Grafiti, 1994.
} 
Soekarno's Old Order era are in accord with the UUD of 1945 as intended by the founding fathers of Indonesia? Are they reflected the paradigm of the 'integralistik' state of Indonesia? If it is so, thus the governmental practices have failed in maintaining with just the pluralistic country in ethnicity, religiosity, culture, and social system of the Indonesian people who inhabited about 17,000 large and small islands. It is no wonder to find that the first constitutional change focused on reducing the power of the president. Among others, the changes have been made to limit the presidential terms of no more than two times (Article 7 of the amended UUD of 1945), the primary power to make a law is transferred to the House of Representatives (DPR) [Art. 5 (1) and 20 of the amended UUD of 1945], the appointment for an ambassador and consular is required the considerations of the DPR (Article 13 of the amended UUD of 1945), the grant for a pardon and rehabilitation should take into account the considerations from the Supreme Court (MA) ${ }^{7}$ [Article 14 (1) of the amended UUD of 1945], the grant for an amnesty and abolition should take into account the considerations from the DPR [Article 14 (2) of the amended UUD of 1945], the grant for a title, decoration, and other honors should follow the law (Article 15 of the amended UUD of 1945). The spirit behind these constitutional changes is to reduce the presidential powers and, at the same time, to strengthen the functions of the House of Representatives.

\footnotetext{
${ }^{7}$ Hereinafter cited as MA
}

The existence of the MPR in the pre-amended UUD of 1945 has been questioned in term of its position as the highest state institution. Within this position, the MPR becomes superior to all other primary state institutions - i.e.: the President, the DPR, the MA, the DPA (Supreme Advisory Council), and the BPK (State Audit Agency).

The role of the MPR in representing the sovereignty of the Indonesian people is also doubted on whether this institution is truly reflecting the Indonesian people primarily because most of its members are appointed by the President and not elected by the people. Furthermore, for decades the MPR has served more in the inaugural ceremony rather than in the election for the president. Therefore, in the third amendment, the function of the MPR was reduced and the MPR no longer positioned as the sole state institution that representing the sovereignty of the Indonesian people. ${ }^{8}$

The shifts on the authority of the President, the DPR, and the MPR - i.e.: the role of the President that no longer dominating the governmental powers, the strengthened role of the DPR, and the lowering position of the MPR that no longer as the highest state institution reflecting the paradigm shift in administering the state.

These shifts, for many of the experts in constitutional law, indicate that the today's constitutional system in Indonesia is categorized as a pure presidential

\footnotetext{
${ }^{8}$ In the amended UUD of 1945 , it defines in the Article 1 (2) of the amended UUD of 1945 that the sovereignty belongs to the people and exercised in accordance with the Constitution.
} 
sys-tem. ${ }^{9}$ However, some other experts are doubt it because they have found that some of the characteristics of a parliamentary system are obviously still there. ${ }^{10}$

\section{Institutional Changes}

Among the institutional changes is the elimination some of the state institutions, such as the Supreme Advisory Councilthrough the deletion of Chapter IV Article 16 of the UUD of 1945 . The DPA has served as the institution that responsible to provide answers to the President's question. The DPA also has the rights to deliver a proposal to the President. As the primary state institution with advisory functions, the DPA has had no significant roles and essential contributions to the state's administration throughout the history. It was found that the DPA in the last two decades has served as a place for the retired state officials.

Another form of constitutional changes is the establishment of new institutions, such the Senate (DPD). The emergence of the DPD is closely linked

\footnotetext{
${ }^{9}$ Shepherd L. Witman and John J. Wuest, Comparative Government, New Jersey: Littlefield, Adams \& Co., 1963. Witman, Shepherd L. and John J. Wuest provide the characteristic of a presidential system as follows: 1) It is based upon the separation of power principle; 2) There is executive has no power to dissolve the legislative nor must he resign when he loses the support of the majority of its membership; 3 ) There is no mutual responsibility between the president and his cabinet; the latter is wholly responsibility to the chief executive; 4) The executive (the chief executive) is chosen by the electorate.

${ }^{10}$ The DPR owns the characteristics of a parliamentary system, such as: having the rights for an interpellation, the rights for inquiry, and the freedom of expression [Article 20A (2) of the amended UUD of 1945].
}

to the idea of bicameralism. Following the tradition in a unitary state, it is a softbicameralism that has been chosen. Although, due to the fact that the future policy of regional autonomy tends to be a federalist one, some political scientists believe that a strong-bicameralism is more appropriate for Indonesia. ${ }^{11}$ Within the soft bicameralism, the role of the DPD is not equal to the DPR, whereas the DPR remains stronger than the $\mathrm{DPD}^{12}$ - even though the Article 22D of the Constitution granted the DPD a significant role as the local representatives.

Since the Indonesian Parliament is represented by three chambers - i.e.: the MPR, the DPR, and the DPD, Asshiddiqie named the parliamentary structure in Indonesia as 'tricameralism' - mainly be-cause each of these three Parliamentary institutions has its own authority, administrative organization, and chairmen of their own. ${ }^{13}$

Another new primary state institution is the Constitutional Court. The Constitutional Court is a phenomenon of the twentieth century. Austria is the first country in the world that establishes a Constitutional Court. The establishment of this judiciary institution has been inspired by the idea of Hans Kelsen (in 1920s). In Indonesia, the establishment of the Constitutional Court is in line with the democratization process appeared in the Reformation era.

Another reason to establish the MK is to receive a particular role of the MPR which related to a constitutional adjudi-

\footnotetext{
${ }^{11}$ Jimly Asshiddiqie, Konstitusi \& Konstitutionalisme Indonesia, Jakarta: MK-RI, $3^{\text {rd }}$ Ed. 2006, p187.

${ }^{12}$ Note 7

${ }^{13}$ Note 7, pp 188-189
} 
cation. ${ }^{14}$ This transfer of constitutional authority - from the MPR to the MK - is resulted from the structural change of the MPR itself that is now no longer serving as the highest state institution. The institutional structure in the post-amended UUD of 1945 implements the separation of powers that based on the principle of 'checks and balances' relationship among the primary state institutions. In other words, the state powers are now equally shared by three branches - i.e.: legislative, executive and judiciary - that mutually control one another which respect to the regulations determined in the Constitution.

Theoretically, the existence of such Constitutional Court has associated with the case of Marbury vs. Madison in the United States of America in $1803^{15}$

\footnotetext{
${ }^{14}$ Note 7, p250.

${ }^{15}$ Jimly Asshiddiqie, Model-Model Pengujian Konstitusional di Berbagai Negara, $1^{\text {st }}$ Ed., Jakarta: MK-RI, 2006, p16-20. Marbury vs. Madison was a landmark United States Supreme Court case in which the Court formed the basis for the exercise of judicial review in the United States under Article III of the Constitution. The landmark decision helped define the boundary between the constitutionally separate executive and judicial branches of the American form of government. The case resulted from a petition to the Supreme Court by William Marbury, who had been appointed Justice of the Peace in the District of Columbia by President John Adams but whose commission was not subsequently delivered. Marbury petitioned the Supreme Court to force the new Secretary of State, James Madison, to deliver the documents. The Court, with John Marshall as Chief Justice, found firstly that Madison's refusal to deliver the commission was both illegal and correctible. Nonetheless, the Court stopped short of ordering Madison (by writ of mandamus) to hand over Marbury's commission, instead holding that the provision of the Judiciary Act of 1789 that enabled Marbury to bring his claim to the Supreme Court was itself unconstitutional, since it purported to extend the Court's original jurisdiction beyond
}

which, later on, became a hot topic that widely debated among experts. At the moment, there are 78 countries that have established Constitutional Court. Hence the presence of the MK in Indonesia should be seen at least from three things: firstly, as the worldwide constitutional practices; secondly, as the development of the constitutional theory, and; thirdly, as the practical need to reform the Indonesian Constitution.

The emergence of the Judicial Commission (KY) is actually motivated by the changing needs of the Supreme Court itself. The Supreme Court was originally served as the Supreme Court of public courts, religious courts, administrative courts, and military courts. Each of these courts has their own administrations and jurisdictions - except the latest one that administered under the military organization. The idea to put all the four courts under one roof of the MA is intended to provide justice for all that free from any interventions/ influences of other state powers.

Previously, the controlling body toward the behavior of the judges is assigned internally by the MA through the Panel of Honorary Judges (MKH). Such internal control is considered having some weaknesses and its account-ability is doubted by public because the process is not transparent. Therefore, an independent body is needed and the $\mathrm{KY}$ is formed. Hence the formation of the KY is intended to improve the supervision toward the judges. The amendedConstitution authorizes the KY to provide recommendations on the appoint-

that which Article III established. The petition was therefore denied. 
ment a Supreme Court justice as well as other authorities in order to preserve and uphold the honor, dignity, and the behavior of judges [Article 24B (1) of the amended-Constitution].

Another new invented institution in the amended-Constitution is the Commission for General Elections (KPU). Like the KY, the KPU is also an independent commission. The KPU manages for fair general elections.

The overall constitutional changes toward the state institutions can be seen from two perspectives: ${ }^{16}$

Firstly, hierarchically, the state institutions having two layers, i.e.: in the first layer are the President and VicePresident, the DPR, the DPD, the MPR, the MA, the MK, and the BPK; while in the second layer are the Ministers, the Military, the Police, the KY, the KPU, and the Central Bank.

Secondly, functionality, the state institutions in the amended-Indonesian Constitution can be classified into primary state institutions and supporting state institutions.

The primary state institutions are those institutions that operate the three branches of the state powers, i.e.: the legislative, the executive, and the judiciary. Within the scope of legislative power are the DPR, the DPD, and the MPR. Within the scope of executive power are the President and the Vice President. The Ministers that work to assist the President and the Vice President are also having executive functions as the primary state institutions. Lastly,

\footnotetext{
${ }^{16}$ Jimly Asshiddiqie, Perkembangan dan Konsolidasi Lembaga Negara Pasca Reformasi, Jakarta: MK-RI, $2^{\text {nd }}$ Ed. 2006, pp99-127.
}

within the scope of judicial powers, are the MA and the MK.

The remaining state institutions as mentioned in the Constitution - i.e.: the $\mathrm{BPK}$, the KY, the KPU, the Central Bank, the Ambassadors and Consuls, the Advisory Council for the President (Wantimpres), the TNI (National Military), the National Police, and the Prosecutors - are classified as the supporting state institutions.

Beyond these primary and supporting state institutions that established by constitutional amendments, tens of auxiliary state institutions have been established in response to demands for democratisation and public participation in governance, such as: the National Law Commission (KHN), the Ombudsman of the Republic of Indonesia (ORI - previously called the National Ombudsman Commission (KON), the National Commission on Human Rights (KOMNAS HAM), the Corruption Eradication Commission (KPK), the Indonesian Police Commission (KOMPOLNAS), the Prosecutorial Commission, and so forth. All of these institutions have responsibility for the implementation of national law in Indonesia and, therefore, somehow influencing the works of the constitutional system in Indonesia.

Such auxiliary state institutions, in principle, do not carry out the main functions of the state powers. Most of those auxiliary state institutions are supporting the governmental functions, and some of them supporting the judiciary functions. However, at the moment, none of those auxiliary state institutions are working to support the legislatures. 
The Consequences of the Ongoing Changes

To support these institutional changes, especially in accordance with the presidential system, direct election for the President and the Vice-President becomes very important in the establishment of the presidency. The implementation of a direct presidential election for the first time in Indonesia was conducted in 2004. This two-stage presidential elections was participated by more than 60 million voters out of 140 million registered voters.

In a presidential system, the relation between the President and the DPR takes place according to their respective functions. In nowadays Indonesia, it is interesting to watch how the tensions appear be-tween these two institutions. The strengthened power of the DPR is one of the factors that contributing to the creations of counter-productive and unnecessary tensions. Another factor is a personal relation-ship between the President and the Vice President and their alliance political parties. These relationships are reflected in the composition of the Cabinet as well as the composition of the pro/con fractions of political parties in the DPR when they discussing the executive policies.

It is a practical need of the President/Vice President to tie themselves with political parties in order to avoid stumbling blocks created by a coalition of political parties in the DPR. This need is especially true when the President is not come from a big political party. ${ }^{17}$ In

17 The fact that an elected President/Vice President is not necessarily come from a big political party demonstrates that even big fact, the capability of the Executive to influence members of the DPR is playing an important role in thwarting the use of the rights of the DPR members for interpellation and inquiry from within the DPR itself. Nevertheless, such tension is quite troublesome and damaging the image of the Executive.

Similar phenomena - the tensions between the Local Governments and the Council of Local Representatives (DPRD) - are also occurs at the provincial and district/city levels. The causes may be differs from one to another. One of the examples is the case in Lampung Province, i.e.: the tension between the Governor and the DPRD of Lampung. The current Governor of Lampung is the winner of the repeated/second local elections. Apparently, the Appeal Court decides that the cancellation of the first local elections is illegitimate, so that the repeated/second local elections and its results are not valid. This is the reason why the DPRD of Lampung refuses to cooperate with the current Governor. In fact that the Governor is also has a weak support from the majority political parties in the DPRD of Lampung. While the elected Governor at the first local elections having a wide support from majority political parties in the DPRD of Lampung. However, the Central Government rejects the results from the first local elections.

The case of Lampung above illustrates a complex situation that contributes to the creation of tensions between the Local Executives and the DPRDs. Many other cases from other places have

political parties do not significantly correlate with the people in grassroots level. 
similar story but not the same causes like the case in Lampung. The dismissal of Nur Mahmudi Ismail as a Mayor of Depok is another example. He lost the Appeal Court of West Java, but the Decision of this West Java Appeal Court is later annulled by the Supreme Court.

Although it is just the beginning that Indonesia experiencing the general and local elections for the Executives, but there is an impression of the symptoms of tensions occurs between the Executives and the Legislatures. This situation is recalling to the era of the 1950s. It is feared that the constitutional changes is followed by bad practices if the majority of the Indonesian people are not involve in the statehood maturation processes.

Another thing is the tendency of the politicians - who are holding executive or legislative offices, in the central or locals - to start anticipate the next general/local elections even though they have just run their services for two years - out of the five years of their terms. So, no one really focus working on his/her real duties. The so-called political imaginary (politik pencitraan) is truly sucked [limited] the national political energy.

It is also important to pointing out the impacts of the regional autonomy as created by the Law No. 22 of 1999 with regard to the Central-Local as well as Provincial-District/City relations. The Law No. 22 of 1999 on Local Governance amended the Law No. 5 of 1974 on Local Governance and the Law No. 5 of 1970 on Village Governance. As a reaction to the previous laws on local governance, this Law No. 22 of 1999 re- forms the previous laws and provides a broad local autonomy.

In the implementation of local autonomy, local government administers their territories by their own self, including in managing the natural resources in their areas. In some cases, the resourcerich regions experience a surplus, while the poor areas rely on other economic sources - such as retributions and other income created through the local regulations. As a result, many local regulations, including those that regulate the licenses, are complained by the business people because of their additional costs.

Apart from that, there are also some populist local regulations, such as on health care services, education, and other things that benefit the community. However, it is suspected that the stipulation of those local regulations is motivated by political interests of the local elites who are anticipating the upcoming local elections.

The changes in local governances due to the concept of an almost 'perfect de-centralization' ${ }^{18}$ is motivated the Law No. 22 of 1999 on Local Governance that following up the constitutional changes of the Chapter VI on Local

\footnotetext{
${ }^{18}$ Hans Kelsen, General Theory of Law and State, New York: Russell \& Russel, 1973, p313. "We speak of perfect decentralization when the creation of local norms is final and independent. It final when there is no possibility that the local norm may be abolished and replaced by central norm. The division of the legislative power in the federal State between a central and several local organs furnishes an examples of decentralization that is not final... The creation of local norms is independent if their contents are in no way determined by central norms. Decentralization is accordingly imperfect when a central law contains the general principles to which local legislation has only to give a more detailed application"
} 
Governance Articles 18, 18A and 18B of the amended-Constitution. The concept of decentralization is about dispersal of the powers in administering the state constitutionally. Therefore, the autonomy based on the concept of decentralization should continuously be observed in both normatively and practices.

The consequences in changing the concept of autonomy affect the pattern of Central-Local relationships. Theoretically, the multi-layered of government in a federal state is aim to prevent the domination of the authority of the Federal Government. ${ }^{19}$ Separation of the territorial powers can be seen as a control toward the state powers as well as to reduce the domination of the $\mathrm{Na}$ tional/Federal Government. ${ }^{20}$

In a unitary state, the sovereignty is undivided and unrestricted. ${ }^{21}$ Basically,

\footnotetext{
${ }^{19}$ Alan Norton, International Handbook of Local and Regional Government: A Comparative Analysis of Advanced Democracies, Suffolk: The Ipswich Book Company, reprinted in 1997, pp26-27.

${ }^{20}$ Harun Alrasyid, in Adnan Buyung Nasution, Harun Alrasid, Ichlasul Amal, et.al, Federalisme Untuk Indonesia, $2^{\text {nd }}$ Ed., Jakarta: Kompas, 2000, pp9-10. discusses the terminology of central and local, whereas central government is usually used in a unitary state, while in a federal state the central/federal government is usually called the national government. From a legal perspective, a more precise term used state and region and both are legal entities.

${ }^{21}$ Note 16. p71. Also see Jean Jaques Rousseau, Discourse on Political Economy and The Social Contract, New York: Oxford University Press, 1994, p64. "Sovereignty is indivisible for the same reason that it is untransferable: a will is either general, or it is not; it is the will of the body of the people, or of a part only."; Also see Jean Jaques Rousseau, The Social Contract, London: J.M. Dent \& Sons Ltd, 1991, p201. "Sovereignty, for the same reason as makes it inalienable, is indivisible; for will either is, or is not, general; it is the will either of body of the people, or only of a part of it."
}

the entire power of the state is owned by the Central Government. It means that the Central Government rules and shapes the composition of the Local Governments, including the types and the wide of the autonomy which is in accord to its own initiative. An autonomous region, according to Wolhoff, is also organizing and assisting the Central Government activities in the region (medebewind). The Central Government remains controlling the supervisory toward the autonomous regions. ${ }^{22}$ In principle, in a unitary state, the authority re-mains in the hands of the Central Government for any intensive interventions to the local areas. However, these authorities referred only in a general formulation in a constitution. $^{23}$ The Central Government is entitled to regulate the whole country, while the Local Governments are authorized to regulate and manage their own areas in so long that they have not been regulated by the Central Government. ${ }^{24}$

If it is carefully observed, the Central-Local relationship in the postamended UUD of 1945, especially after the enactment of the Law No. 22 of 1999, tends to shift to the characteristics of a federal state. One of the evidence is that the Central Government almost lost its control toward the Local Governments in exercising their local autonomy. Meanwhile, the relation-ship between the Provincial Government and

${ }^{22}$ G. J. Wolhoff,Pengantar Ilmu Hukum Tata Negara Republik Indonesia, Jakarta: Timun Mas NV, 1955, pp96-97.

${ }^{23}$ Amrah Muslimin, Aspek-Aspek Hukum Otonomi Daerah, Bandung: Alumni, 1978, p17

${ }^{24} \mathrm{R}$. Tresna, Bertamasya Ke Taman

Ketatanegaraan, Bandung: Dibya, N/A, pp2930. 
the District/Municipality Governments can be said functionally disconnected. Since the enactment of the Law No. 32 of 2004, the local autonomy shift to the 'relative autonomy model., 25

\section{CONCLUSION}

The revolutionary constitutional changes have happened in Indonesia and the implementation of these constitutional changes is continuing underway every single day so that growing the impacts of these constitutional changes into many sectors/fields and all governmental levels - from the central to the provincial to

\footnotetext{
${ }^{25}$ Gerry Stoker in Richard Batley and Gerry Stoker (ed), Local Government in Europe, 1991, p5-6. "The relative model, this model gives an independence to local authorities while not denying the reality of the nation state. The emphasis is on giving freedom of action to local authorities within a defined framework of powers and duties. Central government relations with local authorities are therefore determined largely by legislation. Controls are limited. Local authorities raise most of their revenue through direct taxation. Within the relative autonomy model local authorities may pursue policies which they share with central government or which differ from those advocated by central government." The Agency Model, this is the model in which local authorities are seen mainly as agencies for carrying out central government's policies. This is ensured by detailed specification in legislation, the development of regulations and the operation of controls. The interaction model, (In this model it is difficult to define the spheres of action of central and local government, because they are involved in a complex pattern of relations, in which the emphasis is on mutual influence. The political processes of central and local government are closely inter-relatedpossibly through the dual mandate-with issues often being resolved by mutual discussion. The officers of both levels are closely involved in joint discussion of projects and plans. In this model it is difficult to define responsibilities, since emphasis is on working together. Local government finance will involve both taxes and grants, but taxes may be shared and grant levels protected."
}

the district/ municipality to the village governances. For academic circles, these constitutional changes and their impacts are a challenging subject to be studied. It is most likely that such constitutional studies will provide the explanations on the particular circumstances and the specific characteristics of the Indonesian constitutional system.

\section{REFERENCES}

Asshiddiqie, Jimly. 2006. Konstitusi \& Konstitutionalisme Indonesia, $3^{\text {rd }} \mathrm{Ed}$. Jakarta: Mahkamah Konstitusi Republik Indonesia.

2006. Model-Model Pengujian

Konstitusional di Berbagai Negara, $1^{\text {st }}$ Ed. Jakarta: Mahkamah Konstitusi Republik Indonesia.

2006. Perkembangan dan Konsolidasi Lembaga Negara Pasca Reformasi, $2^{\text {nd }} E d$. Jakarta: Mahkamah Konstitusi Republik Indonesia.

Batley, Richard and Gerry Stoker (ed). 1991. Local Government in Europe: Trends and Developments. London: Palgrave Macmillan.

Kelsen, Hans. 1973. General Theory of Law and State, New York: Russell \& Russel.

Muslimin, Amrah. 1978. Aspek-Aspek Hukum Otonomi Daerah. Bandung: Alumni.

Nasution, Adnan Buyung, Harun Alrasid, Ichlasul Amal, et.al.2000. Federalisme Untuk Indonesia, $2^{\text {nd }} E d$. Jakarta: Kompas,

Norton, Alan. 1997. International Handbook of Local and Regional Government: A Comparative Analysis of Advanced Democracies. Suffolk: The Ipswich Book Company. 
Rousseau, Jean Jaques. 1991. The Social Contract. translation and introduction by G.D.H. Cole. revised and augmented by J.H. Brumfitt and John C. Hall. London: J.M. Dent \& Sons Ltd.

1994. Discourse on Political Economy and The Social Contract. translated by Christopher Betts. New York: Oxford University Press.

Sekretariat Negara. 1995. Risalah Sidang BPUPKI dan PPKI. $3^{\text {rd }} E d$. Jakarta: Sekretariat Negara.

Simanjuntak, Marsilam. 1994. Pandangan Negara Integralistik, $1^{\text {st }} \mathrm{Ed}$. Jakarta: Grafiti,

Tresna, R. n/a. Bertamasya Ke Taman Ketatanegaraan. Bandung: Dibya.

Witman, Shepherd L. and John J. Wuest. 1963. Comparative Government. New Jersey: Littlefield, Adams \& Co.

Wolhoff, G. J. 1955. Pengantar Ilmu Hukum Tata Negara Republik Indonesia, Jakarta: Timun Mas NV. 